\title{
ECONOMIC VIABILITY OF CERRADO VEGETATION MANAGEMENT UNDER CONDITIONS OF RISK
}

\author{
Simão Corrêa da Silva ${ }^{1}$, Antonio Donizette de Oliveira ${ }^{2}$, Luiz Moreira Coelho Junior ${ }^{3}$, José Luiz Pereira de Rezende ${ }^{4}$
}

(received: February 10, 2010; accepted: January 28, 2011)

\begin{abstract}
Cerrado vegetation is Brazil's second largest biome, comprising about 388 municipalities in Minas Gerais state alone and serving as an important source of natural resources. A large share of the wood charcoal produced in Minas Gerais is sourced from Cerrado vegetation. The objective of this work is to assess the economic viability of Cerrado vegetation management for wood charcoal production, under conditions of risk. The study site is a fragment of Cerrado subjected to five levels of intervention as to basal area removal. For risk analysis, the Monte Carlo method was applied, using charcoal price, interest rate and land value as input variables, and using Net Present Value as output variable over an infinite planning horizon. It was concluded that introducing risk in the economic analysis of the various Cerrado management regimes helped provide additional information to that obtained by deterministic analysis, improving understanding and ensuring safety in decision-making about the economic viability of such regimes. For all treatments, the probability of VPL being negative increases with increasing cutting cycle lengths. For all treatments, the optimal cutting cycle is ten years. Treatments where a larger volume of wood was removed proved less prone to risks of economic inviability since they secure more revenue than treatments where less wood was removed.
\end{abstract}

Key words: Monte Carlo simulation, forest economics, risk analysis, Cerrado vegetation.

\section{VIABILIDADE ECONÔMICA DO MANEJO DO CERRADO EM CONDIÇÕES DE RISCO}

\begin{abstract}
RESUMO: O Cerrado é o segundo maior bioma do Brasil. Em Minas Gerais, ele abrange cerca de 388 municípios, sendo uma importante fonte de recursos naturais. Uma grande parcela do carvão vegetal produzido no Estado é proveniente da vegetação do cerrado. Objetivou-se, com este trabalho, analisar a viabilidade econômica do manejo da vegetação do cerrado para a produção de madeira para carvão vegetal em condição de risco. A área de estudo foi um fragmento de cerrado submetido a cinco niveis de intervenção em relação a retirada de área basal. Para a análise de risco, utilizou-se o método de Monte Carlo, tendo como variáveis de entrada, o preço do carvão, a taxa de juros e o valor da terra, e, como variável de saída, o Valor Presente Líquido para horizonte infinito. Concluiu-se que a introdução do risco na análise econômica dos diversos regimes de manejo da vegetação do cerrado propiciou a obtenção de informações adicionais às obtidas pela análise determinística, o que melhorou a compreensão e aumentou a segurança para a tomada de decisão em relação à viabilidade econômica desses regimes. Para todos os tratamentos estudados, a probabilidade do VPL ser negativo aumenta com o aumento do ciclo de corte. Para todos os tratamentos, o ciclo de corte ótimo foi de dez anos. Os tratamentos em que se retirou maior volume de madeira mostraram-se menos susceptiveis a riscos de inviabilidade econômica por propiciarem a obtenção de mais renda que os tratamentos em que se retirou menos madeira.
\end{abstract}

Palavras-chave: Simulação de Monte Carlo, Economia Florestal, análise de risco, vegetação de cerrado.

\section{INTRODUCTION}

The Brazilian Cerrado covers an area of roughly two million $\mathrm{km}^{2}$, equivalent to $23 \%$ of the Brazilian territory. It is the country's second largest biome, second only to the Amazon Forest, extending from marginal areas of the Amazon Forest down to Paraná state. In other parts of South America, the Cerrado is also present in Bolivia, Paraguay and Venezuela (RATTER et al., 1997).
In Minas Gerais alone, the Cerrado covers an area of $384,366 \mathrm{~km}^{2}$ and embraces 388 municipalities (PEREIRA et al., 1997). Minas Gerais state is the largest producer and consumer of wood charcoal for the steel industry, having consumed 21.17 million meters of charcoal in 2008 (ASSOCIAÇÃO MINEIRA DE SILVICULTURA - AMS, 2009).

The Cerrado was the first supplier of wood for charcoal production to assist the steel industry of Minas

\footnotetext{
${ }^{1}$ Agronomic Engineer, Professor M.Sc. in Forest Engineering - Instituto Federal do Amazonas - Av. 7 de setembro, 1975, Centro - 69020-120 Manaus, AM, Brasil - simaocorrea@hotmail.com

${ }^{2}$ Forest Engineer, Professor, Dr. in Forest Science - Departamento de Ciências Florestais - Universidade Federal de Lavras - Cx. P. 3037 - 37200-000 Lavras, MG, Brasil - donizete@dcf.ufla.br

${ }^{3}$ Economist, Dr. in Forest Engineering, Researcher in Socioeconomics - Intituto Agronômico do Paraná/IAPAR - Rodovia BR 163, Km 188 85825-000 - Santa Tereza do Oeste, PR, Brasil-1mcjunior@hotmail.com

${ }^{4}$ Forest Engineer, PhD in Forest Economy - Departamento de Ciências Florestais/DCF - Universidade Federal de Lavras/UFLA - Cx. P. 3037 37200-000 - Lavras, MG, Brasil - jlprezen@dcf.ufl a.br
} 
Gerais state. In 1980, 85.8\% of the total charcoal input consumed in Brazil was sourced from native forests. This percentage decreased in the following years, reaching 24.6\% in 1997 (REZENDE et al., 2002). However, the supply of charcoal sourced from nonnative forests failed to meet the increase in demand by steel plants. Thus, in $2008,36.2 \%$ of the charcoal consumed in Minas Gerais was sourced from native forests (AMS, 2009).

Several authors have analyzed the economic viability of using wood from Cerrado vegetation to manufacture charcoal for the steel industry, including Oliveira et al. (1998, 2002) and Rezende et al. (1986). In these studies, economic analysis followed a deterministic approach based on classic methods of investment analysis that include Net Present Value (VPL) and Internal Rate of Return (TIR).

Actual reality may nevertheless be poorly captured by these economic indicators (BRUNI et al., 1998). There is no certainty that expected project estimates will match reality, since there is not enough ability to predict every factor affecting the future, whether favorably or unfavorably. Thus, acceptance of a project with a positive VPL also entails uncertainty because it is based on a cash flow which in turn relies on uncertain estimates (LAPPONI, 2007).

Globalization and the complexity of reality cause uncertainties and market risks to hinder assessment of project efficiency. According to Securato (2007), risk is the probability of events occurring that will generate loss or uncertainty.

Within this context, risk measurement and analysis techniques provide not only additional information to VPL or TIR results but also a perception of the intrinsic characteristic of a project and the impact of likely future events on the decision of accepting the project (LAPPONI, 2007).

Moore and Weatherford (2005) argue that the Monte Carlo method can be used as an alternative method for project assessment whereby risks involved are plainly expressed and easy to understand so as to help decisionmaking. Indicators thus go from being deterministic to becoming stochastic or probabilistic.

This work aims to assess the economic viability of Cerrado vegetation management for charcoal production, under conditions of risk.

Cerne, Lavras, v. 17, n. 2, p. 141-149, abr./jun. 2011

\section{MATERIAL AND METHODS}

\subsection{Database}

The study site is a fragment of Fazenda Vitória, an estate owned by V\&M Florestal and located in the municipality of Coração de Jesus, Minas Gerais state.

The above fragment falls into the 'Cerrado sensu stricto' vegetation category, having been subjected to exploration in past decades, though the intensity of intervention is unknown. The area lies in the northern part of Minas Gerais state, $490 \mathrm{~km}$ away from Belo Horizonte, at an a altitude of $800 \mathrm{~m}$, having flat relief.

According to Köppen classification, the study region falls into the 'Aw' group: dry tropical climate, average annual precipitation of $820 \mathrm{~mm}$ and average annual temperature of $25^{\circ} \mathrm{C}$.

In 1986, the State Forest Institute (IEF) set up an experiment in the above study site consisting of six treatments, with $50 \%, 70 \%, 80 \%, 90 \%$ and $100 \%$ removal of the total basal area, besides a control treatment (no intervention). The experiment covered an area of 30 hectares and treatments were distributed randomly in five blocks, to a total of 30 plots 1 ha each.

\subsection{Investment analysis under condition of risk}

Project investments presuppose the existence of economic, financial, technological, administrative, legal and natural risks. Risks presuppose the possibility of something going wrong within an estimated probability distribution (COELHO JUNIOR et al., 2008).

According to the above authors, due to its ease of use, the Monte Carlo method provides several estimation alternatives for the probability distribution prior to decision-making, offering advantages over other simulation theories.

The risk analysis using the Monte Carlo simulation technique is presented in four stages, as follows.

\subsubsection{Model development}

In order to assess investment, taking into account the relevant risks and uncertainties, the following cash flow was used, as provided in Figure 1.

Table 1 provides the volume of removed timber in $\mathrm{m}^{3} /$ ha at the moment of intervention in 1986, in inventories (1996, 1998 and 2004) and for prognoses (October 2010, December 2016, February 2023 and April 2029). 


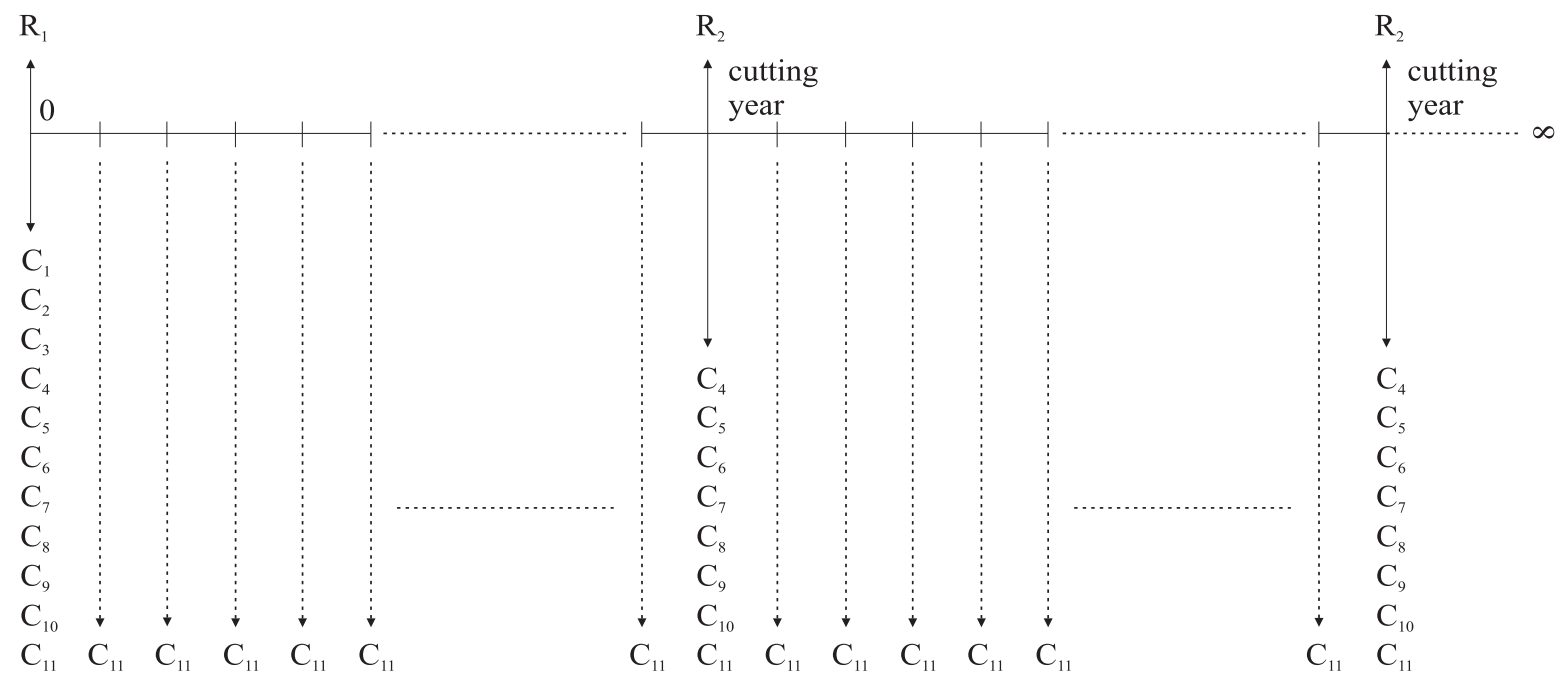

C1: Topographic survey; C2: Inventory and management plan preparation; C3: Road and firebreak construction; C4: Tree marking for harvesting; C5: Road and firebreak maintenance; C6: Felling, limbing, bucking and stacking; C7: Log hauling; C8: Transportation to charcoal kiln; C9: Carbonization; C10: Freight to plant; C11: Annual cost of land; R1: Revenue year 0; R2: Revenue cutting cycle year.

Source: Oliveira (2006).

Figure 1 - Cash flow for Cerrado vegetation management.

Figura 1 - Fluxo de caixa para o manejo da vegetação do cerrado.

Table 1 - Volumes of removed timber (RET) for each treatment and cutting cycle.

Tabela 1 - Volumes de madeira removidos (RET) nos tratamentos e ciclos de corte.

\begin{tabular}{lccccc}
\hline & \multicolumn{5}{c}{ Treatments } \\
\cline { 2 - 6 } Month/Year & $50 \%$ & $70 \%$ & $80 \%$ & $90 \%$ & $100 \%$ \\
& RET & RET & RET & RET & RET \\
\hline 1986 & 10.81 & 15.13 & 17.29 & 19.45 & 21.61 \\
Feb/1996 & 16.76 & 22.97 & 21.48 & 24.30 & 36.70 \\
Jun/1998 & 18.90 & 24.68 & 26.10 & 29.68 & 44.18 \\
Aug/2004 & 20.72 & 27.08 & 29.32 & 33.78 & 50.75 \\
Oct/2010 & 26.18 & 32.91 & 39.52 & 41.99 & 60.92 \\
Dec/2016 & 28.24 & 34.03 & 43.57 & 44.65 & 64.34 \\
Feb/2023 & 30.17 & 35.00 & 47.11 & 47.30 & 67.18 \\
Apr/2029 & 31.93 & 35.86 & 50.05 & 49.90 & 69.43 \\
\hline Source: Oliv & & & & &
\end{tabular}

Source: Oliveira (2006)

Table 2 presents costs involved in charcoal production using wood from Cerrado vegetation in northern Minas Gerais.

\subsubsection{Identification of risks and uncertainties}

To conduct the analysis it is necessary to identify opportunities and threats influencing the relevant project variables. Independent variables considered as input variables (inputs) included value of land, charcoal price and interest rate. To measure input uncertainties, a triangular distribution was used attributing maximum, minimum and most likely values to these variables (Table 3 ).

2.2.3 Identification of analysis variables or output variables

The net present value method over an infinite planning horizon (VPL ${ }_{\infty}$ ) was used in order to define the optimal economic cutting cycle and to assess the different Cerrado management regimes, under deterministic conditions. The formula used for VPL ${ }_{\infty}$ calculation was developed by Oliveira (2006), as follows:

where:

$$
\mathrm{VPL}_{\infty}=V P L+\frac{V F L}{(1+i)^{n}-1}+P T
$$

$V P L=$ Net present value;

$V F L=$ Net final value;

$P T=$ Price of land;

$i=$ Annual interest rate;

$n=$ Cutting cycle duration, in years.

Cerne, Lavras, v. 17, n. 2, p. 141-149, abr./jun. 2011 
Table 2 - Costs involved in charcoal production.

Tabela 2 - Custos de produção do carvão vegetal.

\begin{tabular}{|c|c|c|c|}
\hline Items & Unit & Year of occurrence & Value (R\$) \\
\hline \multicolumn{4}{|l|}{ Implementation } \\
\hline Topographic survey & ha & 0 & 4.00 \\
\hline Inventory and management plan preparation & ha & 0 & 15.00 \\
\hline Road and firebreak construction & ha & 0 & 54.00 \\
\hline \multicolumn{4}{|l|}{ Harvest } \\
\hline Tree marking for harvesting & ha & Cutting years & 12.00 \\
\hline Road and firebreak maintenance & ha & Cutting years & 10.63 \\
\hline Tree felling, limbing, bucking and stacking & $\mathrm{m}^{3}$ & Cutting years & 6.60 \\
\hline Log hauling to roadside & $\mathrm{m}^{3}$ & Cutting years & 2.20 \\
\hline Transportation to charcoal kiln & $\mathrm{m}^{3}$ & Cutting years & 4.40 \\
\hline Carbonization & mdc & Cutting years & 8.00 \\
\hline Freight to plant & mdc & Cutting years & 14.50 \\
\hline \multicolumn{4}{|l|}{ Cost of land } \\
\hline Value of land & ha & - & 400.00 \\
\hline Cost of land $-(i=6 \%$ p.a. $)-[400,00 \times \mathrm{i}]$ & ha & Annual & 24.00 \\
\hline
\end{tabular}

Factor $\left(\mathrm{m}^{3} / \mathrm{mdc}\right)=1.3636$

$\mathrm{mdc}^{*}=$ cubic meter of charcoal

Source: Oliveira (2006)

Table 3 - Price of land and charcoal and interest rate.

Tabela 3 - Preço da terra e do carvão e taxa de juros.

\begin{tabular}{lcccc}
\hline Items & Unit & Minimum value & Most likely value & Maximum value \\
\hline Value of Land & $\mathrm{R} \$ / \mathrm{ha}$ & 0.00 & 400.00 & $1,000.00$ \\
Charcoal Price & $\mathrm{R} \$ \mathrm{ha}$ & 60.67 & 72.80 & 101.92 \\
Interest Rate & $\%$ & 2 & 6 & 10 \\
\hline
\end{tabular}

The VPL is given by the difference between the value of revenues and costs occurring in the year when treatments were implemented $(1986=$ year 0$)$ and the VFL is given by the difference between the value of revenues and costs occurring in the base year defining the cutting cycle $(1996=10$-year cutting cycle $=$ year 10 ; $1998=12$-year cutting cycle $=$ year $12 ; \ldots ; 2029=43$-year cutting cycle $=$ year 43 ).

The VPL ${ }_{\infty}$ of different management regimes was considered an output variable (outputs).

\subsubsection{Simulation and model analysis}

For the risk analysis,@Risk software was used (PALISADE CORPORATION, 1995). According to
Bentes-Gama (2003), this program enables applying the Monte Carlo method to simulate values of random and independent variables (revenue and cost) and, as a result, to obtain values of the profit variable.

After assembling the cash flow, 10,000 simulations were run for the input variable ( $\mathrm{VPL}_{\infty}$ ), using pseudorandom numbers, in other words, a series of values was generated for this variable so as to obtain its simple and cumulative frequency distribution.

\section{RESULTS AND DISCUSSION}

Table 4 provides results of economic analysis, as conducted by Oliveira (2006), without taking risks into account (deterministic analysis). Higher $\mathrm{VPL}_{\infty}$ values were

Cerne, Lavras, v. 17, n. 2, p. 141-149, abr./jun. 2011 
obtained when shorter cutting cycles were used, regardless of treatment. For a given cutting cycle, the higher the level of basal area intervention, the higher profitability is, as expressed by $\mathrm{VPL}_{\infty}$.

Table 5 provides results of simulations run in order to obtain $\mathrm{VPL}_{\infty}$ occurrence probabilities for each treatment and cutting cycle being studied, while Figure 2 provides simple and cumulative frequency distributions of this indicator for the 10 -year cutting cycle. The treatment in which $50 \%$ of basal area is removal, in the 10-year cutting cycle, $5 \%$ of VPL values are above $\mathrm{R} \$ 1,134.29$. In the 43 -year cutting cycle, $5 \%$ of VPL values are above $\mathrm{R} \$ 244.36$. The same trend is observed in the remaining situations.

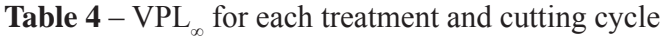

Tabela 4 - VPL $L_{\infty}$ para os tratamentos e ciclos de corte

\begin{tabular}{cccccc}
\hline \multirow{2}{*}{$\begin{array}{c}\text { Cutting } \\
\text { Cycle }\end{array}$} & $50 \%$ & $70 \%$ & $80 \%$ & $90 \%$ & $100 \%$ \\
\cline { 2 - 6 } Treatments / VPL & $(\mathrm{R} \$ / \mathrm{ha})$ \\
10 & 233.82 & 522.15 & 528.69 & 664.32 & $1,086.89$ \\
12 & 180.38 & 417.97 & 502.37 & 637.32 & $1,027.81$ \\
18 & 12.91 & 196.48 & 276.26 & 384.40 & 652.35 \\
24 & -43.59 & 111.02 & 213.54 & 283.90 & 482.13 \\
30 & -103.31 & 27.93 & 126.73 & 183.29 & 332.79 \\
37 & -148.94 & -31.63 & 57.10 & 108.86 & 221.69 \\
43 & -174.35 & -63.74 & 17.30 & 68.15 & 160.43 \\
\hline
\end{tabular}

Source: Oliveira (2006)

Table 5 - VPL $L_{\infty}$ probabilities $(\mathrm{R} \$ /$ ha) for each treatment and cutting cycle.

Tabela 5 - Probabilidades do $V P L_{\infty}(R \$ / h a)$ para os tratamentos e ciclos de corte.

\begin{tabular}{|c|c|c|c|c|c|c|c|}
\hline \multirow{3}{*}{ Probabilities } & \multicolumn{7}{|c|}{ Cutting cycle (years) } \\
\hline & 10 & 12 & 18 & 24 & 30 & 37 & 43 \\
\hline & \multicolumn{7}{|c|}{$50 \%$ Treatment } \\
\hline $5 \%$ & -205.79 & -249.79 & -389.54 & -441.47 & -493.37 & -535.98 & -560.61 \\
\hline $15 \%$ & -32.18 & -83.32 & -237.69 & -291.54 & -348.61 & -392.43 & -419.98 \\
\hline $25 \%$ & 87.78 & 34.36 & -131.13 & -189.92 & -252.05 & -301.51 & -327.50 \\
\hline $35 \%$ & 184.23 & 127.86 & -47.13 & -107.74 & -171.96 & -221.61 & -250.24 \\
\hline $45 \%$ & 273.55 & 213.65 & 26.46 & -34.92 & -103.32 & -156.11 & -185.59 \\
\hline $55 \%$ & 364.10 & 300.06 & 100.68 & 34.57 & -37.79 & -92.22 & -123.76 \\
\hline $65 \%$ & 465.25 & 396.37 & 180.14 & 108.37 & 33.19 & -26.56 & -59.59 \\
\hline $75 \%$ & 589.92 & 514.89 & 272.29 & 195.99 & 113.34 & 47.36 & 10.47 \\
\hline $85 \%$ & 774.43 & 683.20 & 400.57 & 315.00 & 216.49 & 141.32 & 100.26 \\
\hline \multirow[t]{2}{*}{$95 \%$} & 1134.29 & 1020.74 & 642.65 & 533.73 & 400.20 & 298.39 & 244.36 \\
\hline & \multicolumn{7}{|c|}{$70 \%$ Treatment } \\
\hline $5 \%$ & 33.61 & -50.12 & -223.80 & -298.88 & -367.10 & -419.56 & -449.86 \\
\hline $15 \%$ & 228.04 & 136.09 & -62.36 & -140.89 & -213.37 & -268.19 & -299.23 \\
\hline $25 \%$ & 363.12 & 265.02 & 56.73 & -27.89 & -111.60 & -173.31 & -206.67 \\
\hline $35 \%$ & 481.92 & 375.10 & 149.13 & 60.12 & -28.06 & -91.20 & -125.93 \\
\hline $45 \%$ & 593.34 & 476.89 & 232.37 & 138.93 & 47.30 & -22.17 & -59.33 \\
\hline $55 \%$ & 711.15 & 585.88 & 318.94 & 217.37 & 119.03 & 46.50 & 7.32 \\
\hline $65 \%$ & 841.27 & 701.69 & 412.12 & 304.52 & 195.84 & 118.37 & 75.24 \\
\hline $75 \%$ & 1002.61 & 849.62 & 526.60 & 406.25 & 285.94 & 199.86 & 154.35 \\
\hline $85 \%$ & 1249.48 & 1072.62 & 686.51 & 547.47 & 409.05 & 304.86 & 250.80 \\
\hline $95 \%$ & 1753.92 & 1528.71 & 1009.33 & 831.08 & 635.12 & 489.38 & 415.70 \\
\hline
\end{tabular}

Continua...

To be continued... 
Tabela 2 - Continua...

Table 2 - Continued...

\begin{tabular}{|c|c|c|c|c|c|c|c|}
\hline \multirow{3}{*}{ Probabilities } & \multicolumn{7}{|c|}{ Cutting cycle (years) } \\
\hline & 10 & 12 & 18 & 24 & 30 & 37 & 43 \\
\hline & \multicolumn{7}{|c|}{$80 \%$ Treatment } \\
\hline $5 \%$ & 45.62 & 22.85 & -155.50 & -207.93 & -278.22 & -335.15 & -371.52 \\
\hline $15 \%$ & 240.76 & 216.61 & 14.34 & -43.71 & -122.34 & -181.98 & -217.79 \\
\hline $25 \%$ & 374.95 & 347.53 & 137.44 & 74.74 & -8.17 & -79.19 & -117.91 \\
\hline $35 \%$ & 493.10 & 464.25 & 232.77 & 168.12 & 79.48 & 6.35 & -35.05 \\
\hline $45 \%$ & 602.32 & 573.34 & 323.00 & 253.52 & 159.15 & 82.04 & 36.47 \\
\hline $55 \%$ & 717.97 & 686.72 & 413.23 & 340.41 & 236.33 & 155.63 & 107.62 \\
\hline $65 \%$ & 845.48 & 811.65 & 513.69 & 436.30 & 325.44 & 233.94 & 184.82 \\
\hline $75 \%$ & 1003.14 & 967.10 & 636.90 & 554.12 & 428.23 & 326.69 & 269.16 \\
\hline $85 \%$ & 1236.29 & 1200.99 & 814.35 & 722.72 & 570.43 & 452.61 & 383.88 \\
\hline \multirow[t]{2}{*}{$95 \%$} & 1720.72 & 1687.07 & 1163.47 & 1061.37 & 857.71 & 687.71 & 589.55 \\
\hline & \multicolumn{7}{|c|}{$90 \%$ Treatment } \\
\hline $5 \%$ & 154.90 & 128.64 & -68.21 & -147.06 & -224.88 & -286.45 & -321.63 \\
\hline $15 \%$ & 358.69 & 332.71 & 114.07 & 22.88 & -67.92 & -129.76 & -166.81 \\
\hline $25 \%$ & 503.51 & 475.87 & 241.61 & 146.95 & 49.86 & -22.99 & -64.19 \\
\hline $35 \%$ & 631.94 & 601.99 & 346.22 & 242.35 & 141.47 & 62.91 & 20.34 \\
\hline $45 \%$ & 753.84 & 722.50 & 443.56 & 333.64 & 222.27 & 140.89 & 93.54 \\
\hline $55 \%$ & 880.36 & 848.54 & 542.62 & 423.42 & 304.45 & 215.84 & 166.61 \\
\hline $65 \%$ & 1024.60 & 988.90 & 654.65 & 525.90 & 395.96 & 296.94 & 242.87 \\
\hline $75 \%$ & 1197.46 & 1163.46 & 790.65 & 650.03 & 501.24 & 391.27 & 332.02 \\
\hline $85 \%$ & 1462.32 & 1429.64 & 996.12 & 832.76 & 651.12 & 522.14 & 452.38 \\
\hline \multirow[t]{2}{*}{$95 \%$} & 2008.82 & 1975.00 & 1400.79 & 1194.06 & 949.47 & 765.73 & 663.37 \\
\hline & \multicolumn{7}{|c|}{$100 \%$ Treatment } \\
\hline $5 \%$ & 449.43 & 399.06 & 130.73 & 4.06 & -109.74 & -191.81 & -238.81 \\
\hline $15 \%$ & 705.99 & 650.67 & 339.36 & 196.48 & 68.68 & -28.32 & -79.98 \\
\hline $25 \%$ & 891.20 & 830.72 & 484.33 & 326.29 & 193.74 & 91.86 & 33.70 \\
\hline $35 \%$ & 1054.46 & 991.69 & 613.91 & 441.90 & 294.44 & 183.27 & 121.40 \\
\hline $45 \%$ & 1219.32 & 1152.03 & 736.95 & 549.80 & 390.29 & 268.44 & 202.28 \\
\hline $55 \%$ & 1390.99 & 1319.65 & 866.80 & 666.50 & 485.79 & 353.32 & 280.92 \\
\hline $65 \%$ & 1593.27 & 1519.13 & 1015.62 & 791.45 & 594.55 & 450.38 & 368.26 \\
\hline $75 \%$ & 1845.94 & 1768.77 & 1203.63 & 950.98 & 729.74 & 562.78 & 469.71 \\
\hline $85 \%$ & 2216.04 & 2131.94 & 1484.11 & 1200.22 & 931.64 & 727.63 & 610.78 \\
\hline $95 \%$ & 3022.61 & 2931.19 & 2081.61 & 1721.09 & 1360.75 & 1061.58 & 892.27 \\
\hline
\end{tabular}

Cerne, Lavras, v. 17, n. 2, p. 141-149, abr./jun. 2011 

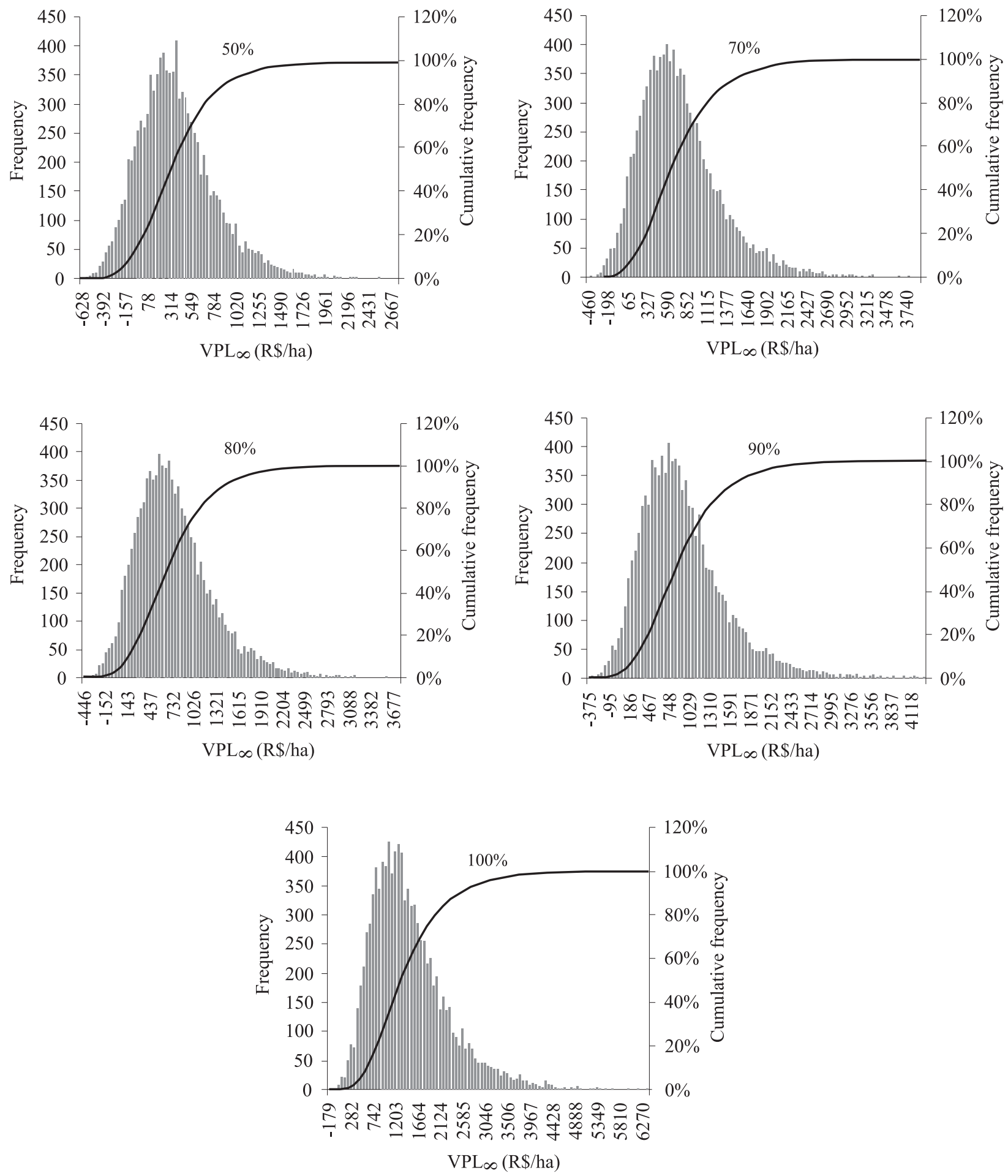

Figure $2-\mathrm{VPL}_{\infty}$ value histograms for each treatment, in the 10-year cutting cycle.

Figura 2 - Histogramas dos valores de VPL para os tratamentos, no ciclo de corte de 10 anos. 
Table 6 provides probabilities of $\mathrm{VPL}_{\infty}$ being below zero, indicating economic inviability of the relevant treatment. The $50 \%$ treatment shows higher occurrence probabilities of a negative $\mathrm{VPL}_{\infty}$. The probability ranges from $17.80 \%$ in the 10 -year cycle to $73.49 \%$ in the 43 -year cycle, indicating that Cerrado management following this prescription entails high risk. The clear cutting treatment $(100 \%$ of vegetation removed), on the other hand, entails low risk even in a 24-year cutting cycle (4.83\%).

The above check can also be done through analysis of numerical data in Table 7. In the 50\% treatment, the expected $\mathrm{VPL}_{\infty}$ value (or mean value) is $\mathrm{R} \$ 369.46$, and its standard deviation is $\mathrm{R} \$ 412.87$. Thus, with a little less than one standard deviation a zero $\mathrm{VPL}_{\infty}$ is attained. As for the $100 \%$ treatment, 1.8 standard deviations are necessary for a negative $\mathrm{VPL}_{\infty}$. Additionally, the coefficient of variation of the $50 \%$ treatment (111.74\%) shows higher risk than the coefficient of the $100 \%$ treatment $(55.74 \%)$.

The mean $\mathrm{VPL}_{\infty}$, or expected $\mathrm{VPL}_{\infty}$ value, whose calculation is risk based (Table 7) is invariably higher than the VPL ${ }_{\infty}$ whose calculation is based on deterministic analysis (Table 4). Take for instance the $80 \%$ treatment, with risks being computed, the mean $\mathrm{VPL}_{\infty}$ is $\mathrm{R} \$ 735.91$. In the deterministic analysis, the $\mathrm{VPL}_{\infty}$ is $\mathrm{R} \$ 528.69$.

The probability of $\mathrm{VPL}_{\infty}$ being below values calculated by Oliveira (2006) was also assessed without computing risks. Probabilities in Table 8 indicate that in the $100 \%$ treatment, 10 -year cutting cycle, the $\mathrm{VPL}_{\infty}$ calculated with risks being computed has a $36.77 \%$ chance of being lower than the $\mathrm{VPL}_{\infty}$ shown in Table $4(\mathrm{R} \$ 1,086.89)$, where risks were not computed.

Table 6 - Probabilities of VPL being negative for each treatment and cutting cycle.

Tabela 6 - Probabilidades de o VPL ser negativo para os tratamentos e ciclos de corte.

\begin{tabular}{cccccc}
\hline \multirow{2}{*}{ Cutting Cycle } & \multicolumn{5}{c}{ Treatments } \\
\cline { 2 - 6 } & $50 \%$ & $70 \%$ & $80 \%$ & $90 \%$ & $100 \%$ \\
\hline 10 & 17.80 & 3.92 & 3.51 & 1.68 & 0.09 \\
12 & 21.80 & 7.22 & 4.21 & 2.03 & 0.17 \\
18 & 41.32 & 20.00 & 13.88 & 7.93 & 2.00 \\
24 & 50.21 & 27.99 & 18.66 & 13.18 & 4.83 \\
30 & 60.41 & 39.01 & 25.80 & 20.41 & 10.34 \\
37 & 68.49 & 48.24 & 34.14 & 32.24 & 17.06 \\
43 & 73.49 & 53.99 & 39.99 & & 21.85 \\
\hline
\end{tabular}

Table 7 - A descriptive statistic of $\mathrm{VPL}_{\infty}$ for each treatment, in the 10-year cutting cycle.

Tabela 7 - Estatística descritiva do VPL $L_{\infty}$ para os tratamentos, no ciclo de corte de 10 anos.

\begin{tabular}{lccccc}
\hline \multirow{2}{*}{ Statistics } & \multicolumn{5}{c}{ Treatments $/ \mathrm{VPL}_{\infty}(\mathrm{R} \$ / \mathrm{ha})$} \\
\cline { 2 - 6 } & $50 \%$ & $70 \%$ & $80 \%$ & $90 \%$ & $100 \%$ \\
\hline Minimum value & -627.53 & -460.24 & -446.09 & -375.34 & -179.15 \\
Maximum value & $2,734.04$ & $3,915.06$ & $3,760.95$ & $4,305.28$ & $6,402.05$ \\
Mean (expected value) & 369.46 & 734.95 & 735.91 & 907.38 & $1,457.84$ \\
Standard deviation & 412.87 & 536.26 & 518.23 & 576.68 & 812.59 \\
Variance & $170,459.60$ & $287,579.40$ & $268,567.00$ & $332,564.00$ & $660,309.60$ \\
Coefficient of variation (\%) & 111.74 & 72.97 & 70.42 & 63.56 & 55.74 \\
\hline
\end{tabular}

Cerne, Lavras, v. 17, n. 2, p. 141-149, abr./jun. 2011 
Table 8 - Probability of the $\mathrm{VPL}_{\infty}$ of risk analysis being lower than the $\mathrm{VPL}_{\infty}$ of deterministic analysis.

Tabela 8 - Probabilidade de o VPL $L_{\infty}$ da análise de risco situar-se abaixo do $V P L_{\infty}$ da análise determinística.

\begin{tabular}{cccccc}
\hline \multirow{2}{*}{$\begin{array}{c}\text { Cutting } \\
\text { Cycles }\end{array}$} & $50 \%$ & $70 \%$ & $80 \%$ & $90 \%$ & $100 \%$ \\
\hline 10 & 40.47 & 38.65 & 38.16 & 37.58 & 36.77 \\
12 & 41.18 & 39.18 & 38.51 & 37.82 & 37.13 \\
18 & 43.08 & 40.76 & 39.92 & 39.00 & 38.05 \\
24 & 43.90 & 41.55 & 40.45 & 39.66 & 38.67 \\
30 & 45.00 & 42.43 & 41.10 & 40.41 & 39.16 \\
37 & 46.17 & 43.52 & 41.89 & 41.19 & 39.55 \\
43 & 47.07 & 44.34 & 42.31 & 41.68 & 40.13 \\
\hline
\end{tabular}

\section{CONCLUSIONS}

The introduction of risk in the economic analysis of several Cerrado management regimes helped obtain additional information to that obtained by deterministic analysis, improving understanding and ensuring safety for decision-making about the economic viability of such regimes.

For all treatments being studied, the probability of VPL being negative increases with increasing cutting cycle lengths.

Treatments with larger volumes of wood being removed proved less prone to risks of economic inviability than treatments with less wood being removed, for the reason that they secure more revenue.

\section{REFERENCES}

ASSOCIAÇÃO MINEIRA DE SILVICULTURA. Números e índices em Minas Gerais em 2008. Disponível em: <http:// www.silviminas.com.br>. Acesso em: 10 nov. 2009.

BENTES-GAMA, M. M. Análise de econômica de sistemas agroflorestais em Machadinho d Oeste, Rondônia. 2003.

112 p. Tese (Doutorado em Ciência Florestal) - Universidades Federal de Viçosa, Viçosa, 2003.

BRUNI, A. L.; FAMÁ, R.; SIQUEIRA, J. O. Análise de risco na avaliação de projetos de investimento: uma aplicação do Método de Monte Carlo. Caderno de Pesquisas em Administração, São Paulo, v. 1, n. 6, p. 62-74, 1998.

COELHO JUNIOR, L. M.; REZENDE, J. L. P.; OLIVEIRA, A. D.; BORGES, L. A. C.; SOUZA, A. N. Análise de investimento de um sistema agroflorestal sob situação de risco. Cerne, Lavras, v. 14, n. 4, p. 368-378, 2008.

LAPPONI, J. C. Projetos de investimento na empresa. Rio de Janeiro: Elsevier, 2007. 488 p.

MOORE, J.; WEATHERFORD, L. R. Tomada de decisão em administração com planilhas eletrônicas. 6 . ed. Porto Alegre: Bookman, 2005. 644 p.

OLIVEIRA, A. D.; LEITE, A. P.; BOTELHO, S. A.; SCOLFORO, J. R. S. Avaliação econômica da vegetação de cerrado Submetida a diferentes regimes de manejo e de povoamentos de eucalipto plantado em monocultivo. Cerne, Lavras, v. 4, n. 1, p. 34-56, 1998.

OLIVEIRA, A. D.; MELLO, A. A.; SCOLFORO, J. R. S.; REZENDE, J. L. P.; MELO, J. I. F. Avaliação econômica da regeneração da vegetação de cerrado, sob diferentes regimes de manejo. Revista Árvore, Viçosa, v. 26, n. 6, p. 715-726, 2002.

OLIVEIRA, S. L. Análise técnica e econômica do manejo sustentável da vegetação do cerrado. 2006. 64 p. Dissertação (Mestrado em engenharia Florestal) - Universidade Federal de Lavras, Lavras, 2006.

PALISADE CORPORATION. Risk analysis and simulation add-in for Microsoft Excel or Lotus 1-2-3. Version, 1. New York, 1995.

PEREIRA, G.; AGUIAR, J. L. P.; MOREIRA, L.; BEZERRA, H. S. Área e população do cerrado. Pesquisa Agropecuária Brasileira, Brasília, v. 32, n. 7, p. 759-763, 1997.

RATTER, J. A.; RIBEIRO, J. F.; BRIDGEWATER, S. The Brazilian cerrado vegetation and threats to its biodiversity. Annals of Botany, London, v. 80, p. 223-230, 1997.

REZENDE, J. L. P.; COELHO JUNIOR, L. M.; OLIVEIRA, A. D. A economia florestal mineira vis-à-vis a economia florestal brasileira. In: SIMPÓSIO DE SÓLIDOS DE EUCALIPTO: AVANÇOS CIENTÍFICOS E TECNOLÓGICOS, 2002, Lavras. Anais... Lavras: UFLA, 2002. CD-ROM.

REZENDE, J. L. P.; VALE, A. B.; MINETTE, L. Estudo comparativo da produção de carvão da madeira da vegetação nativa e de Eucalyptus spp. Viçosa, MG: SIF/IBDF, 1986. 45 p.

SECURATO, J. R. Decisões financeiras em condições de risco. 2. ed. São Paulo: Saint Paul, 2007. 264 p.

Cerne, Lavras, v. 17, n. 2, p. 141-149, abr./jun. 2011 